РОЗВИТОК ЕМПАТІЇ МАЙБУТНІХ УЧИТЕЛІВ МУЗИЧНОГО МИСТЕЦТВА В КОНТЕКСТІ ІНКЛЮЗИВНОЇ ОСВІТИ

\title{
DEVELOPMENT OF EMPATHY OF FUTURE TEACHERS OF MUSICAL ART IN THE CONTEXT OF INCLUSIVE EDUCATION
}

Стаття присвячена одній з актуальних проблем сучасної системи освіти - підготовиі вчителів музичного мистецтва до роботи в умовах розвитку і поширення інклюзивноі освіти. Розглядається один з аспектів підготовки здобувачів освіти коледжів культури і мистецтв, а саме розвиток емпатії як професійно-ціннісної орієнтації, педагогічної здібності й інтегративної властивості особистості вчителя для ефективної взаємодії з дітьми, які мають особливі потреби. Основна увага зосереджена на діагностиці рівня емпатичних тендениій майбутніх учителів музичного мистецтва (констатувальний етап експерименту), правилах формування емпатії й основних вправах для їі розвитку, давно відомих у практичній психології та запропонованих автором. Зазначено недоліки навчальних планів коледжів культури і мистецтв, що не беруть до уваги необхідність підготовки здобувачів освіти до роботи з дітьми, які мають особливі потреби. Також розглядаються можливі варіанти вдосконалення навчальних програм із педагогіки та психології в коледжах культури і мистецтв у напрямі орієнтації самостійної роботи здобувачів освіти на опанування навичок тренування емпатії, можливості введення спецкурсу (за вибором закладу освіти), застосування елементів пасивної педагогічної практики, що передує активній, як шляхи для більш ефективного формування емпатії. Автор пропонує власні вправи для розвитку названої інтегративної властивості особистості (емпатійний аналіз музичного твору, аналіз сторінки в соціальній інтернет-мережі, обмін емпатійними враженнями), актуалізує необхідність проведення нестандартних занять із залученням фрахівців інклюзивно-ресурсних чентрів, соціальних педагогів, асистентів учителя й інших). Розглядаються можливості вдосконалення шляхів тренування емпатіі в межах педагогічної практики (сумісно з учнем), педагогіки та психології (ігри, тренінгові вправи, творчі завдання, цілеспрямоване спостереження, рефрлексія), основ медичних знань, методики навчання грі на інструменті та спецкурсу «Аксіологічні засади діяльності вчителя музичного мистецтва». Підкреслюється також необхідність розроблення якісної технології фоормування емпатії майбутніх учителів музичного мистецтва 3 наступним упровадженням у практику освітньої діяльності коледжів культури і мистецтв, яка дозволить музичним вихователям здійснювати продуктивну педагогічну діяльність (у межах інклюзивної освіти) у школах естетичного виховання та закладах початкової мистецької освіти. Ключові слова: емпатія, інклюзивна освіта, емпатійний аналіз музичного твору, ціле- спрямоване спостереження, діагностика емпатичних тендениій.

The article is devoted to one of the actual problems of the modern system of education - the preparation of teachers of musical art to work in the conditions of development and dissemination of inclusive education. In particular, one aspect of the preparation of colleges of culture and arts is considered, namely the development of empathy as a professional - value orientation, pedagogical abilities and integrative properties of the teacher's personality to effectively interact with children who are special needs. The main attention is focused on the diagnosis of the level of empathetic trends of future teachers of musical art (the ascertaining stage of the experiment), the rules of formation of empathy and basic exercises for its development; have long been known in practical psychology and proposed by the author. The disadvantages of curricula of colleges of culture and arts are indicated that they do not take into account the need for educational applicants to work with children who are special needs. Also, possible options for improving educational programs on pedagogy and psychology in colleges of culture and arts in the direction of orientation of self-students studying of applicant of education for mastering the skills of empathy training, the possibility of introducing a special course (at the choice of educational institution), the use of passive pedagogical practices, preceding the active, as the ways for more efficient formation of empathy. The author offers her own exercises for the development of the named integrative property of the individual (empathetic analysis of the music work, the analysis of the page in the Internet, exchange of empathetic impressions), actualizes the need for non-standard classes with the involvement of specialists in inclusive resource center's, social educators, assistants of the teacher, etc.). The possibilities for improving the ways of training empathy within pedagogical practice (team wise with students), pedagogy and psychology (games, training exercises, creative tasks, purposeful observation, reflection), bases of medical knowledge, methods of learning play the musical instrument and special course "Axiological Principles of the Teacher of Musical Art". It is also emphasized by the need to develop high-quality technology for the formation of empathy of future teachers of musical art, followed by introducing into the practice of educational activities of colleges of culture and arts, which will allow musical educators to carry out productive pedagogical activities (within inclusive education) in schools of aesthetic education and institutions of elementary artistic education. Key words: empathy, inclusive education, empathetic analysis of musical work, purposeful observation, diagnosis of empathetic trends.

культури і мистецтв

імені Івана Карабиця

Постановка проблеми в загальному вигляді. Друге десятиріччя XXI ст. позначилося на практиці освітньої діяльності активним упровадженням дистанційного навчання, посиленням уваги до андрагогіки, збільшенням відсотка ІКТ серед методів навчання, необхідністю реалізації інклюзивного навчання майже в усіх ланках освіти, серед яких і мистецька позашкільна освіта. У зв'язку 
із цим постала нагальна потреба підготовки вчителів музичного мистецтва до естетичного виховання учнів 3 особливими потребами як у складі основних груп вихованців (ансамблі, сольфеджіо, музична література тощо), так і під час індивідуальної роботи (спеціальність).

Виділення не вирішених раніше частин загальної проблеми. Суцільна невідповідність навчальних планів коледжів мистецтв для підготовки таких кадрів є незаперечною: у навчальних планах відсутні дисципліна «Вікова психологія», у навчальних програмах 3 основ педагогіки та психології відсутні теми з патологічної психології, інклюзивної педагогіки (тільки оглядово (загальний обсяг дисципліни - 72 години), курс є не практичним, а лекційним за навчальним планом) тощо. Проте кількість учнів 3 особливими потребами у школах мистецтв щороку збільшується, що свідчить про актуальність висвітленої проблеми (за показниками 2018 р. 165000 дітей в Україні мали особливі освітні потреби). Лист Міністерства освіти і науки України від 31 серпня 2020 р. № 1/9-495 «Щодо організації навчання осіб 3 особливими освітніми потребами в закладах загальної середньої освіти у 2020/2021 навчальному році» містить роз'яснення щодо організації освітньо-виховного процесу в інклюзивних класах за допомогою асистента вчителя, асистента учня, учителя-дефектолога, супроводу фрахівців інклюзивно-ресурсних центрів. Але в закладах позашкільної мистецької освіти таких посад не передбачено (тільки асистент дитини), тому необхідність підготовки самого вчителя до роботи 3 дітьми з особливими потребами виступає на перший план.

Аналіз останніх досліджень і публікацій. Проблемам інклюзивної освіти присвячені роботи Дж. Алвіна, Л. Брусиловського, І. Зайцевої, О. Заярнюк, Н. Квітки, Н. Малій, О. Мащенко, М. Поваляєвої, О. Ребрової, Т. Скрипник, В. Тарасун, Е. Уорика, Г. Хворової й інших. На нашу думку, у публікаціях названих науковців широко висвітлено можливі методики роботи з учнями з особливими потребами, а питання підготовки педагогічних працівників до роботи з такими учнями залишаються на периферії дослідників.

Мета статті. Завданням даної статті $€$ висвітлення рівня розвитку емпатії майбутніх учителів музичного мистецтва й опис методик ії̈ розвитку для більш ефективної взаємодії викладачів із вихованцями з особливими потребами в ланці позашкільної мистецької освіти.

Виклад основного матеріалу. Т. Стратан виділяє серед профресійно значущих інтегративних якостей особистості вчителя здатність до емпатії, яка $є$ з'єднувальною ланкою музичної та педагогічної культури і яка сприяє ефективному формуванню педагогічної майстерності вчителя школи естетичного виховання засобами мистецтва [5].
Емпатія в багатьох підручниках із педагогічної майстерності визначається як одна з педагогічних здібностей. Тобто професіограма вчителя музичного мистецтва [3, с. 92] містить цю властивість особистості у своїй структурі як обов'язкову під час роботи з основною групою учнів. Ми вважаємо необхідним посилений розвиток цієї властивості в майбутніх учителів музичного мистецтва з огляду на перспективу взаємодії 3 дітьми 3 особливими потребами. За логікою дослідження необхідним було діагностування стану розвитку емпатії майбутніх учителів музичного мистецтва на сучасному етапі підготовки.

У констатувальному етапі експерименту взяли участь здобувачі освіти Бахмутського фрахового коледжу культури і мистецтв ім. І. Карабиця, Маріупольського коледжу мистецтв, Полтавського фрахового коледжу мистецтв ім. М.В. Лисенка. Експеримент було проведено серед здобувачів освіти I-II курсів музичного коледжу, коледжу мистецтв та музичного училища. Експериментом було охоплено 300 здобувачів освіти.

Нами була використана методика діагностики здатності до емпатії за питальником А. Мехрабієна та Н. Епштейна, адаптована Л. Столяренко [4, с. 671]. Отримані дані дали змогу за шкалою Н. Епшпейна узагальнити результати в таблиці й унаочнили на рисунку.

Таблиця 1

Діагностика рівня емпатичних тенденцій майбутніх учителів музичного мистецтва за методикою А. Мехрабієна та Н. Епштейна (констатувальний етап експерименту)

\begin{tabular}{|l|c|c|c|c|}
\hline \multirow{2}{*}{$\begin{array}{c}\text { Рівні і } \\
\text { показники }\end{array}$} & \multicolumn{2}{|c|}{$\begin{array}{c}\text { Контрольна } \\
\text { група } \\
150 \text { осіб }\end{array}$} & \multicolumn{2}{|c|}{$\begin{array}{c}\text { Експериментальна } \\
\text { група } \\
\text { 150 осіб }\end{array}$} \\
\cline { 2 - 5 } & $\%$ & $\begin{array}{c}\text { Кількість } \\
\text { осіб }\end{array}$ & $\%$ & $\begin{array}{c}\text { Кількість } \\
\text { осіб }\end{array}$ \\
\hline Високий & 6 & 9 & 8 & 12 \\
\hline Середній & 62 & 93 & 60 & 90 \\
\hline Низький & 32 & 48 & 32 & 48 \\
\hline
\end{tabular}

Настільки низький показник рівня емпатичних тенденцій майбутніх учителів музичного мистецтва свідчить про нерозуміння здобувачами освіти ролі емпатії у структурі особистості педагогамузиканта; орієнтацію переважно на виконавську діяльність, а не музично-педагогічну; відсутність навичок застосування у практичній діяльності комунікативно-емпатійної взаємодії з учнем [3, с. 118].

Отримані показники свідчать про необхідність розвитку емпатійних властивостей майбутніх учителів музичного мистецтва для забезпечення ефрективності взаємодії з вихованцями з особливими потребами і для фрормування емпатії як профресійно-ціннісної орієнтації у структурі особистості педагога-музиканта. 


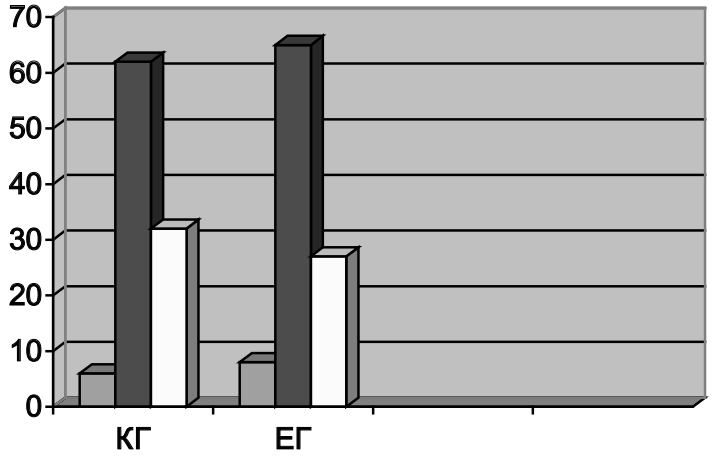

Рис. 1. Співвіднесення рівня емпатичних тенденцій майбутніх учителів музичного мистецтва (констатувальний етап експерименту)

Психолог А. Бахтіна визначає емпатію як усвідомлене співпереживання емоційному стану інших людей, здатність розпізнавати, що вони відчувають, та перейматись їхнім станом. Дослідниця відзначає, що це складна внутрішня робота, що вимагає великого ресурсу. Науковець фрормулює низку правил, що сприяють розвитку цієї властивості, які ми, у свою чергу, застосували для розвитку емпатії майбутніх учителів музичного мистецтва, включили їх до змісту лекцій із психології та педагогіки:

- щире бажання зрозуміти іншу людину (глибокі конструктивні відносини можна створити тільки коли ми не є байдужими);

- співпереживання, а не оцінка (відмовитись від автоматичних реакцій і не оцінювати);

- приймання того фракту, що кожна людина живе у своїй психологічній реальності (поважати відмінності в переконаннях, навіть якщо ми їх не поділяємо) [1].

Поглиблюючи отриманий здобувачами освіти матеріал на лекційних заняттях, ми додали вправи з розвитку емпатії до самостійної роботи студентів (за порадами А. Бахтіної):

- активне цілеспрямоване спостереження за людьми й ідентисрікація їхніх почуттів (на зупинках транспорту, під час спілкування, аудиторія на концерті);

- тренування активного слухання з підтримкою візуального контакту;

- віддзеркалення емоцій іншої людини (вислухування того, що людина говорить, та переказ цього з акцентом на її почуттях);

- спілкування з людьми, які не схожі на вас, 3 намаганням зрозуміти їхні мотиви, щоб уникнути домінування тунельного мислення;

- читання художньої літератури та перегляд психологічних фрільмів (аналіз переживань персонажа);

- ігри та тренінги, в основі яких необхідність поставити себе на місце іншої людини або спиратись на її асоціації (наприклад, «Імаджинаріум»);
- складання карт емоцій (до переліку із 30-ти емоцій додати опис ситуацій, у яких ви ії переживали, для співвіднесення з реакціями інших людей і більш точного розуміння їхніх почуттів);

- вправа на обмін ролями (опис від іншої особи потоку сприйняття, почуттів тощо, яка розвиває здатність бачити світ із позиції іншої людини) [1].

До описаних вправ можемо додати вправи із творами мистецтва, як-от емпатійний аналіз музичного твору за умовним планом:

- Які емоції та почуття передає твір?

- За допомогою яких засобів музичної виразності передаються слухачеві настрій твору й окремі емоційні стани?

- Чи однозначно сприймаються емоції та почуття музичного твору слухачами? Від чого залежить неоднозначність сприймання почуттів, переданих у музичному творі?

- Чи мали вплив фракти біограсрії композитора та час / місце написання музичного твору на емоційний зміст музики?

- Як передані емоції та почуття допомагають виразити естетичний зміст твору? Виховну ідею?

- Наведіть приклади інших музичних творів зі схожим емоційним навантаженням.

- Наведіть приклади музичних творів, у яких емоційний зміст найбільш однозначно сприймається слухачами.

Як матеріал для розвитку емпатії майбутніх учителів музичного мистецтва можна використовувати не тільки аналіз психічного життя персонажів художніх творів та фрільмів, а і матеріали сторінок у соціальній інтернет-мережі. Сторінки деяких користувачів можуть містити розширену інсрормацію, яка досить часто набуває фрорми потоку сприйняття як прямого психологічного зображення персонажа, яким у даному разі $€$ власник сторінки (оповідач або розповідач). Сторінку такого користувача, на нашу думку, можна розглядати як художній твір, що не має кінця, тобто протікає в динаміці. У такому тлумаченні можна твердити, що зміст сторінки користувача для реципієнтів відповідає таким ознакам художнього твору, як художність та складна організованість. Також варто відмітити цілісність цього утворення, що випливає із цілісності структури особистості (не беручи для аналізу матеріал сторінок дітей та людей із психічними відхиленнями), цілісності людського сприйняття дійсності (чуттєве, емоційне, інтелектуальне), цілісності художнього світу (дійсність, що є, і що може бути) [2, с. 105].

Аналіз матеріалу сторінки в соціальній мережі як художнього твору вимагає від дослідника підготовки: знання кола інтересів автора (для встановлення асоціацій, інтертекстуальних зв'язків), 
елементів біографії (для паралелей із суспільноісторичним процесом), освіти (для з'ясування рівня об'єктивності та професійності висвітлення й оцінки ним подій), знайомство із творами музики, літератури, кіно, комп'ютерними іграми, близькими автору. Звичайно, під час аналізу треба враховувати наявність у соціальній мережі штучних (несправжні, «фрейкові») сторінок, за якими стоїть вигадана особистість (для шахрайства, бізнесу, сайту знайомств тощо), але навіть у такому разі, якщо всі поля сторінки заповнені, вона може бути іноді матеріалом для аналізу. Людина мимоволі застосує деякі елементи свого асоціативного ряду, коли обирає псевдонім з іменем улюбленого (або негативного персонажа), кольорове офрормлення сторінки, пише статус із цитатою шанованого автора або того, кого зневажає тощо. Створена штучна мережева особистість носитиме на собі відбиток ціннісної ієрархії автора, його світогляду, принципів, ідеалів, естетичних смаків, а отже, надаватиме матеріал для розвитку емпатії реципієнта.

На нашу думку, розвиткові емпатії майбутніх учителів музичного мистецтва сприяють і заняття педагогічною практикою (III-IV курси коледжів мистецтв), під час яких обов'язкове встановлення контакту та застосування індивідуального підходу до учня, вік якого коливається від 5 до 16 років. Структура уроку дозволяє додавати вправи для розвитку емпатії, наприклад усний опис художнього змісту музичного твору учнем, малювання твору, асоціації окремих засобів музичної виразності з явищами природи, написання поетичного твору про почуття, передані в музичному творі (за можливості) тощо. Доцільним також $є$ обмін емпатійними враженнями учня та вчителя про їхній настрій і стан на конкретному уроці, наприклад, шляхом добору пісні або іншого музичного твору, що символізує їхній стан сьогодні, або опис стану і настрою за допомогою цитати з вірша, образу персонажа з художніх творів тощо.

Для більш ґрунтовного розвитку емпатії майбутніх учителів музичного мистецтва й орієнтації їх на можливу роботу в інклюзивних класах (чи індивідуально 3 дитиною 3 особливими потребами) під час вивчення дисциплін «Педагогіка та психологія», «Методика навчання грі на інструменті», предмета «Основи медичних знань» ми пропонуємо впровадження нестандартних уроківконсультацій, уроків-зустрічей із фрахівцями інформаційно-ресурсних центрів, асистентами вчителів, соціальними педагогами, які могли б поділитися досвідом роботи зі здобувачами освіти, відповісти на їхні питання, підготувати майбутніх учителів шкіл мистецтв до особливостей роботи у сорері інклюзивної освіти. Ці нестандартні заняття можна проводити як очно, так і дистанційно, за допомогою конференц-зв'язку. Неоціненний досвід здо- бувачам освіти надали б елементи пасивної практики з відвідуванням занять в інклюзивних класах шкіл мистецтв (пасивна практика не передбачена навчальним планом підготовки учителів музичного мистецтва в коледжах культури і мистецтв із 2018 р.), оскільки вони будуються на цілеспрямованому спостереженні, аналізі й оцінці спостережень, порівнянні матеріалів спостережень із вимогами методики й обов'язковою рефлексією здобувача освіти.

Проте наявність онлайн-курсів та відео в мережі Інтернет дозволяє частково компенсувати брак названих вище необхідних новацій для тренування емпатії майбутніх учителів музичного мистецтва. До складу програми дисципліни «Педагогіка та психологія» входить певна кількість годин, відведених на самостійну роботу здобувачів освіти. Ми пропонуємо вводити до структури самостійної роботи елементи пасивної практики в межах закладу освіти (коледж культури і мистецтв), побудовані на спостереженні, із творчими завданнями.

Також зазначимо, що в межах курсів підвищення кваліфікації для вчителів музичного мистецтва наявні години із психології та педагогіки, які містять і теми з інклюзивної освіти. Проте кількість цих годин не задовольняє потребу в якісній підготовці до роботи з вихованцями, що мають особливі потреби.

Тому вважаємо за потрібне ввести додаткові спецкурси, спрямовані на формування профеесійно-ціннісних орієнтацій майбутніх учителів музичного мистецтва, що сприятиме більш якісній підготовці в контексті інклюзивної освіти. Наприклад, спецкурс «Аксіологічні засади діяльності вчителя музичного мистецтва» ґрунтується на цілісності як процесу створення професійно-ціннісних орієнтацій, так і процесу їх засвоєння здобувачами освіти завдяки збільшенню кількості практичних занять $з$ обов'язковою частиною тренінгів.

Розроблена нами програма цієї вибіркової навчальної дисципліни передбачає фрормування виділених нами як стрижневих у структурі спрямованості майбутнього вчителя музичного мистецтва професійно-ціннісних орієнтацій, а саме: креативності, комунікативності, емпатії, біоетики, патріотизму, розгляд їх у взаємозв'язках з іншими компонентами Я-концепції та професіограми педагога-музиканта. Останній модуль програми спрямований на узагальнення і систематизацію знань, засвоєних у перших двох модулях; розв'язання педагогічних завдань; самоаналіз та рефрлексію майбутніх учителів музичного мистецтва; інтерпретацію матеріалу у творчих роботах. Цей модуль забезпечує проєкцію теоретичних знань у сореру практичної профресійної діяльності (драматизацію, створення педагогічних ситуацій, педагогічний експромт, імпровізацію), що пов'язано 3 необхідністю аналізувати ситуацію, обирати стра- 
тегію поведінки, вирішувати проблеми з огляду на морально-ціннісну реґламентацію роботи майбутнього вчителя музичного мистецтва. Описані вправи є складовою частиною загального процесу формування емпатії і можуть доповнюватись відповідно до здібностей і можливостей викладача та здобувачів освіти [3, с. 138].

Висновки. Отже, нами був розглянутий рівень емпатичних тенденцій майбутніх учителів музичного мистецтва, обґрунтована необхідність посиленого розвитку в них емпатії для більш ефективної взаємодії з вихованцями, що мають особливі потреби, розглянуто можливості вдосконалення навчальних програм коледжів культури і мистецтв та можливості введення вибіркової дисципліни (спецкурс), у межах якої можна більш активно фрормувати емпатію. Висвітлені матеріали, звичайно, не є вичерпними, будуть доповнені надалі розробкою технології фрормування емпатії майбутніх учителів музичного мистецтва для здійснення продуктивної педагогічної діяльності в межах інклюзивної освіти.

\section{БІБЛІОГРАФІЧНИЙ СПИСОК:}

1. Бахтина А. 8 упражнений для развития эмпатии. Стиль. URL: https://style.rbc.ru/health/ 5f8dc8439a7947bb36bf1109 (дата звернення: 15.08.2021).

2. Магда П. Інтертекстуальність сторінки у соціальній мережі Інтернет як матеріал для розвитку емпатії. Сучасні педагогіка та психологія: перспективні та пріоритетні напрями наукових досліджень : матеріали Міжнародної науково-практичної консреренції. Київ : ГО «Київська наукова організація педагогіки та психології», 2021. С. 105-108.

3. Магда П. Формування професійно-ціннісних орієнтацій майбутніх учителів музичного мистецтва у процесі вивчення предметів соціально-гуманітарного циклу : дис. ... докт. фрілос.: 015 «Профресійна освіта». Слов'янськ, 2020. 190 с.

4. Основы психологии: практикум / ред.-сост. Л. Столяренко. 3-е изд., доп. и перераб. Ростов-наДону : Феникс, 2002. 704 с.

5. Стратан Т. Формування педагогічної майстерності майбутніх учителів музики засобами мистецтва : автореф. дис. ... канд. пед. наук: 13.00.04. Київ, 1996. 25 c. 